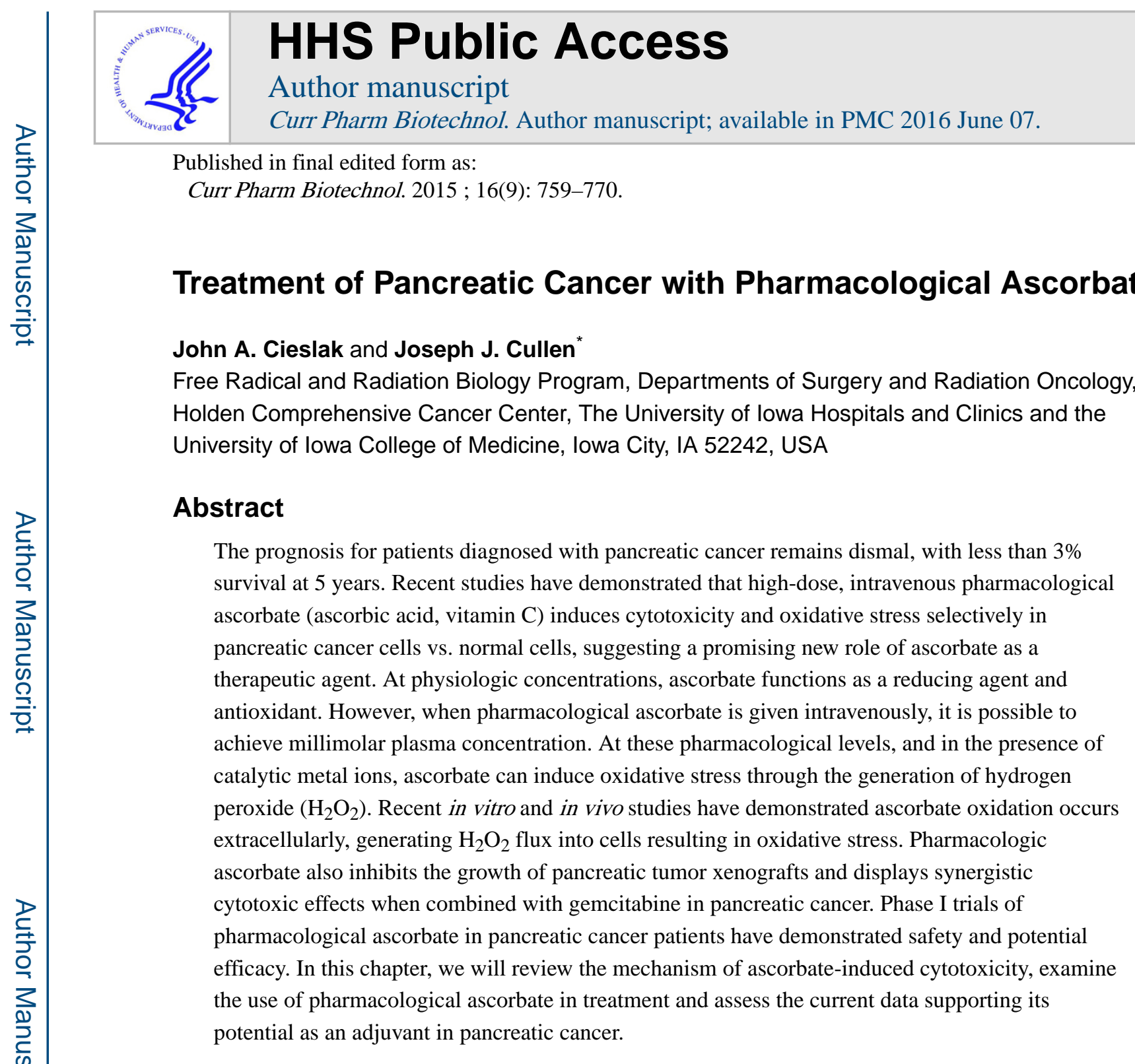

\title{
INTRODUCTION
}

\section{Pancreatic Cancer}

Pancreatic adenocarcinomas, derived from the exocrine pancreas, represent $85 \%$ of all pancreatic neoplasms. Adenocarcinoma of the pancreas is the fourth leading cause of cancer related death in the United States and its incidence is steadily increasing $\left[{ }^{1}\right]$. Current National Cancer Institute (NCI) data estimate that 45,220 men and women (22,740 men, 22,480 women) will be diagnosed with pancreatic cancer in calendar year 2013 (ageadjusted incidence rate of 12.2 per 100,000 men and women per year) $\left.{ }^{2}\right]$. The median age at diagnosis for cancer of the pancreas is 71 years of age and the prognosis is dismal, with an overall 5-year relative survival rate of only $3 \%$, and median age at death of 73 (age-adjusted death rate of 10.9 per 100,000 men and women per year) $\left[{ }^{2}-4\right]$. A recent NCI cancer bulletin

*Address correspondence to this author at the $1528 \mathrm{JCP}$, University of Iowa Hospitals and Clinics, Iowa City, IA 52242, USA; Tel: (319) 353-8297, Fax: (319) 356-8378; ; Email: joseph-cullen@uiowa.edu

CONFLICT OF INTEREST

The author(s) confirm that this article content has no conflict of interest. 
article on pancreatic cancer highlighted the aggressive nature and poor prognosis of pancreatic cancer by stating, "the slow but steady march toward more individualized care in cancer medicine has left pancreatic cancer behind. Patients diagnosed with this disease live no longer today than patients diagnosed two decades ago, despite more than a dozen large clinical trials. Even as many patients with other cancers have benefited from targeted drugs, pancreatic cancer remains as deadly as ever" $\left[{ }^{5}\right]$.

Patients diagnosed with pancreatic cancer usually present late in the disease process with symptoms varying based on tumor location within the pancreas. The most commonly reported symptoms are abdominal/epigastric pain, jaundice, and anorexia/weight loss, and are most commonly associated with cancers located within the head of the pancreas (60$70 \%$ of pancreatic cancers) $\left.{ }^{6}\right]$. Currently, the only potentially curative treatment is surgical resection via pancreaticoduodenectomy, but only $15-20 \%$ of patients have surgically resectable disease at the time of presentation, with $40 \%$ of patients presenting with metastatic disease and the remaining patients presenting with locally advanced tumors.

Even after complete resection, prognosis is poor, with expected 5-year survival rates of approximately $25 \%\left[{ }^{7}-10\right]$. For locally advanced and metastatic disease, median survival is approximately 10 and 6 months, respectively $\left[{ }^{11}\right]$. For the majority of patients with pancreatic cancer, adjuvant chemotherapy and combination radiotherapy remain the only treatment options with the goal of palliating symptoms [ $\left.{ }^{12}\right]$. For the last twenty years, gemcitabine has been the standard of care chemotherapy after a clear improvement in the one-year median survival rate in patients treated with gemcitabine, was demonstrated over those who had received 5-FU. Furthermore, treatment with gemcitabine was associated with a reduction in pain intensity scores, daily analgesic consumption, and an improvement in performance status $\left[^{13}\right]$. A recent multi-site randomized control trial of a chemotherapy regimen consisting of oxaliplatin, irinotecan, fluorouracil, and leucovorin (FOLFIRINOX), demonstrated significantly increased survival compared to patients treated with gemcitabine, as well as prolonged progression-free survival [ $\left.{ }^{14}\right]$. However, FOLFIRINOX was associated with more severe adverse events and added toxicity, which were not well tolerated by many patients. Despite this, FOLFIRINOX is now considered as the first line standard of care treatment for advanced pancreatic cancer in many patients. Even with the modest improvement in survival time attained with FOLFIRINOX, several clinical trials of multiple new therapies have been performed, and no drug or combination of drugs has significantly improved the overall prognosis $\left[{ }^{12}, 15\right]$.

\section{Ascorbate}

Ascorbate (ascorbic acid, Vitamin C) is an essential nutrient for humans and plays a role in several important biochemical functions. Ascorbate is a water-soluble ketolactone with two ionizable hydroxyl groups, making it an excellent reducing agent and anti-oxidant at physiologic concentrations. Indeed, it readily undergoes two consecutive, one electron oxidations to form ascorbate radical ( $\mathrm{Asc}^{\circ}-$ ) and dehydroascorbic acid (DHA), though the ascorbate radical is relatively unreactive due to resonance stabilization of the unpaired electron (Fig. 1) [ $\left.{ }^{16}\right]$. Though ascorbate oxidizes readily, its rate of oxidation is $\mathrm{pH}$ dependent and can be further accelerated by the presence of catalytic metal ions $\left[{ }^{17}\right]$. At 
physiological $\mathrm{pH}$, the autoxidation of ascorbate is fairly slow, with a rate constant of approximately $300 \mathrm{M}^{-1} \mathrm{~s}^{-1}\left[{ }^{18}\right]$.

Ascorbate functions across a various range of cell and organ systems as an anti-oxidant. In general, intracellular ascorbate concentrations are increased compared to extracellular fluids, reaching millimolar concentrations in blood components [ 19,20$]$. However, erythrocytes have intracellular ascorbate levels similar to extracellular plasma [ 21,22$]$. High levels of intracellular ascorbate are hypothesized to help maintain an intracellular reducing environment, but it has also been demonstrated that ascorbate can help reduce extracellular oxidants by transferring electrons across the plasma membrane, or through efflux of ascorbate itself $\left[{ }^{23}, 24\right.$ ]. In addition, millimolar levels of ascorbate are found in the cornea and lens of the eye, which may help protect them from solar radiation damage $\left[{ }^{25}, 26\right]$.

Besides its role as an antioxidant, ascorbate also functions as a co-factor in various enzymatic pathways. Examples include its roles as a reductant in the conversion of dopamine to norepinephrine, as a co-factor for peptidyl glycine a-amidating monooxygenase [ ${ }^{26 \_29}$ ], and as a cofactor for $\mathrm{Fe}^{2+}-2$-oxoglutarate dioxygenases, where it is necessary for maintaining iron in the ferrous state $\left[{ }^{30}, 31\right]$. Additionally, ascorbate is essential in the promotion of collagen synthesis and its proper assembly $\left[{ }^{32}, 33\right]$, the regulation of hypoxia-inducible transcription factor (HIF) $\left[{ }^{34 \_37}\right]$, and as a cofactor for histone demethylation $\left[38 \_41\right]$.

Ascorbate can be synthesized from glucose in plants and most animals, however humans lack functional L-gulonolactone oxidase, the enzyme required for the last step of ascorbate synthesis, and are dependent on dietary intake to maintain essential stores [ $\left.{ }^{42}\right]$. Both ascorbate and dehydroascorbic acid (DHA) are absorbed via the enterocytes of the small intestine. Ascorbate absorption is mediated by $\mathrm{Na}^{+}$-dependent vitamin $\mathrm{C}$ transporters (SVCTs), whereas DHA is absorbed by $\mathrm{Na}^{+}$-independent facilitative glucose transporters (GLUTs) [43_46]. Because plasma glucose concentrations are much higher than plasma DHA concentrations the majority of intracellular ascorbate is absorbed via SVCTs, rather than indirectly through GLUT absorption of DHA [ 47,48 ]. Besides the brush border of enterocytes, SVCTs are also found within renal tubular cells.

Plasma ascorbate concentrations are tightly regulated; both by the limited affinity of SVCT for ascorbate, as well as through a negative feedback loop in which high intracellular ascorbate concentrations leads to down-regulation of SVCT present on the enterocyte membranes [49_51]. Pharmacokinetic modeling has shown that it is a combination of saturable intestinal absorption, tissue accumulation, and renal re-absorption and excretion that determines the bioavailability of ascorbate $[16,52,53]$. As a consequence of this tight regulation, the bioavailability of oral ascorbate (micromolar concentrations) is much lower than what can be achieved when administered intravenously (millimolar concentrations) $\left[{ }^{53}\right]$.

At physiologic concentrations and $\mathrm{pH}$, ascorbate anion $\left(\mathrm{AscH}^{-}\right)$comprises the major species of ascorbate and can readily donate an electron to free radicals such as hydroxyl radical $\left(\mathrm{HO}^{\bullet}\right)$, alkoxyl radical $\left(\mathrm{RO}^{\bullet}\right)$, peroxyl radical $\left(\mathrm{LOO}^{\bullet}\right)$, and thiol radical $\left(\mathrm{GS}^{\bullet}\right)$. It is also 
known to play a pivotal role in the prevention of LDL and lipid peroxidation synergistically with vitamin $\mathrm{E}\left[{ }^{16}, 54 \_57\right]$. The oxidation of AscH-produces ascorbate radical $\left(\mathrm{Asc}^{-\bullet}\right)$, which is relatively unreactive and is reduced back to ascorbate by NADH/NADPH reductases $\left[{ }^{58}\right]$. In the presence of catalytic metal ions, ascorbate can function as a prooxidant and induce oxidative stress as a pro-drug for the delivery of hydrogen peroxide [ $\left[{ }^{17}\right.$, $59,{ }^{60}$ ]. Ascorbate reduces ferric iron to ferrous iron, which is then free to react with oxygen, producing superoxide $\left(\mathrm{O}_{2}{ }^{-}\right)$. Superoxide then dismutates into hydrogen peroxide $\left(\mathrm{H}_{2} \mathrm{O}_{2}\right)$, which in turn reacts with ferrous iron through the Fenton reaction, resulting in generation of reactive oxygen species. This process can also occur at a slower rate in the absence of catalytic metals through autoxidation of ascorbate.

\section{Ascorbate as a Chemotherapeutic Agent}

It has been greater than 50 years since it was first hypothesized that ascorbate may inhibit tumor growth [ $\left.{ }^{61}\right]$ by inhibiting hyaluronidases; preventing the breakdown of the extracellular matrix and therefore cancer cell migration $\left[{ }^{62}, 63\right]$. A clinical benefit for ascorbate in the treatment of cancer was first demonstrated in the early trials of Cameron, Pauling, and Campbell in the 1970s in which increased survival was observed in patients receiving intravenous ascorbate [ $\left.{ }^{64}{ }^{67}\right]$. Cameron and Campbell published case reports of 50 patients treated with high-dose ascorbate, with some report of benefit $\left[{ }^{64}\right]$. Cameron and Pauling then published a follow up study of 100 patients with terminal cancer who were given intravenous ascorbate demonstrating that patients who received ascorbate survived 300 days longer than retrospective control patients with similar disease $\left[{ }^{67}\right]$. However, ascorbate was dismissed as a chemotherapeutic agent following two randomized, double-blinded clinical trials in the 1980s utilizing in which orally administered ascorbate (10 g per day) demonstrated no difference in symptoms or survival between treatment groups and placebo controls $[68,69]$.

It was only later realized after pharmacokinetic studies were performed by Levine and colleagues, that the bioavailability of orally administered ascorbate is much lower than when administered intravenously $\left[{ }^{19},{ }^{70}\right]$. Oral doses of ascorbate ranging from 30 to $100 \mathrm{mg}$ daily produced average fasting plasma concentrations of only $60 \mu \mathrm{M}$. Even doses of 1000 $\mathrm{mg}$ daily produced average fasting plasma concentrations of only $75-80 \mu \mathrm{M}$. As daily doses increased to $2500 \mathrm{mg}$, there were minimal further increases in plasma concentrations [ ${ }^{19}$, $53,{ }^{70}$ ] due to a combination of saturable intestinal absorption, tissue accumulation, and renal re-absorption and excretion [ $\left.{ }^{16}, 52,{ }^{53}\right]$. Riordan and associates found that intravenous administration of ascorbate produced peak plasma concentrations approximately 25 -fold higher than that attained by the same dose given orally $\left[{ }^{71}\right]$. Thus, potentially therapeutic doses are attainable only through parenteral administration $\left[{ }^{72}\right]$. Animal studies using intraperitoneal dosing of ascorbate confirmed that only parenteral injection could produce pharmacologic ascorbate concentrations similar to those obtained by intravenous infusions in humans $\left[{ }^{73}{ }^{75}\right.$ ] These data suggest that the lack of efficacy of ascorbate as a cancer treatment as determined by the previous randomized controlled trials may have been due to the fact that patients were receiving sub-therapeutic doses. This knowledge of ascorbate's pharmacokinetics generated renewed enthusiasm into its potential in the treatment of cancer, 
and several new studies into the efficacy and mechanisms of action of pharmacologic ascorbate were produced.

\section{TREATMENT OF PANCREATIC CANCER WITH PHARMACOLOGICAL ASCORBATE}

\section{In Vitro Studies}

Selective cytotoxicity of pharmacologic ascorbate on cancer cells was first demonstrated in vitro by Chen et al. in $\left.2005{ }^{\left[{ }^{76}\right.}\right]$. In their study, cell viability was decreased in ten cancer cell lines and unchanged in four non-tumorigenic cell types after one-hour exposure to pharmacological ascorbate. Normal cells were unaffected by $20 \mathrm{mM}$ ascorbate, while all but one cancer cell line showed decreased survival with ascorbate exposure; 5 of which had $\mathrm{EC}_{50}$ doses $<4 \mathrm{mM}$. Interestingly, cell death was suggested to be dependent upon $\mathrm{H}_{2} \mathrm{O}_{2}$ formation. Further work expanded these studies to 43 cancer cell lines $\left[{ }^{73}\right]$. Again, the results demonstrated similar results with the $\mathrm{EC}_{50}$ doses of ascorbate less than $10 \mathrm{mM}$ for 34 of the 43 cell lines investigated, and with normal cells insensitive to concentrations of ascorbate exceeding $20 \mathrm{mM}$. Furthermore, the addition of catalase to the medium reversed the decrease in cell viability in multiple cancer types exposed to $10 \mathrm{mM}$ ascorbate $(1 \mathrm{~h})$, supporting they hypothesis that cytotoxicity was mediated by $\mathrm{H}_{2} \mathrm{O}_{2}$. These studies demonstrated that pharmacological doses of ascorbate achievable by parenteral administration of the drug have selective toxicity against cancer cells vs. normal cells.

In the first study specific to pancreatic cancer cell susceptibility to ascorbate, Du et al. demonstrated selective sensitivity of three pancreatic cancer cell lines (MIA PaCa-2, AsPC-1, and BxPC-3) vs. a normal immortalized pancreatic ductal epithelial cell line (H6c7) to 1 hour treatment with both 5 and $10 \mathrm{mM}$ ascorbate $\left[{ }^{77}\right]$. All of the pancreatic cancer cell lines demonstrated decreased cell metabolic viability as well as decreased clonogenic survival when treated with ascorbate [ $\left.{ }^{78}, 79\right]$. This study demonstrated a time and dose-dependent increase in measured $\mathrm{H}_{2} \mathrm{O}_{2}$ production with increased concentrations of ascorbate leading to the hypothesis that ascorbate associated $\mathrm{H}_{2} \mathrm{O}_{2}$ production induced oxidative stress within cancer cells, leading to caspase-independent cell death consistent with autophagy. Indeed, when cells were treated with scavengers of $\mathrm{H}_{2} \mathrm{O}_{2}$, ascorbateassociated decreases in clonogenic survival could be reversed. It was suggested that the difference in sensitivity observed in cancer cells vs. normal cells toward ascorbate might be explained by the low levels of antioxidant enzymes and high levels of endogenous ROS in cancer cells [ $\left.16,80 \_82\right]$.

\section{In Vivo Studies}

Initial studies using intraperitoneal dosing of ascorbate confirmed that only parenteral injection could produce pharmacologic ascorbate concentrations similar to those obtained by intravenous infusion in humans [ $\left.{ }^{73}{ }^{75}\right]$. One study in mice showed that a bolus intraperitoneal injection of ascorbate at a dose of $1 \mathrm{~g} \mathrm{~kg}^{-1}$ resulted in plasma concentration of $15 \mathrm{mM}$, whereas supplementation of the drinking water with the same dose increased plasma concentration to only $50 \mu \mathrm{M}\left[{ }^{75}\right]$, similar to the results of human studies that found 
that pharmacologic concentrations of ascorbate can only be attained via parenteral administration.

In 2008, Levine's group demonstrated [ ${ }^{73}$ ] that in mice bearing glioblastoma xenografts, a single pharmacologic dose of ascorbate produced sustained concentrations of both Asc ${ }^{\bullet-}$ and $\mathrm{H}_{2} \mathrm{O}_{2}$ within the interstitial fluids of the tumor. In contrast, the same pharmacologic ascorbate concentrations in whole blood generated little detectable $\mathrm{Asc}^{{ }^{-}}$- and no detectable $\mathrm{H}_{2} \mathrm{O}_{2}\left[{ }^{83}\right]$. This lack of $\mathrm{Asc}^{\bullet-}$ and $\mathrm{H}_{2} \mathrm{O}_{2}$ in the blood leads to the hypothesis that erythrocytes were acting as a sink, actively recycling Asc ${ }^{\bullet-}$ and $\mathrm{H}_{2} \mathrm{O}_{2}$ via more efficient and redundant $\mathrm{H}_{2} \mathrm{O}_{2}$ catabolic pathways relative to the extracellular fluid [ ${ }^{84}{ }^{89}$ ]. Therefore, pharmacologic ascorbate may serve as a pro-drug for $\mathrm{H}_{2} \mathrm{O}_{2}$ delivery to the tumor extracellular milieu, without accumulation in blood.

Tumor vessels are known to have a much higher permeability as compared to normal endothelium, which may permit the accumulation of macromolecules such as proteins in the interstitial fluid $\left[90,{ }^{91}\right]$. Furthermore, iron, copper, and other catalytic metals are known to associate with damaged protein within the extracellular fluid [ ${ }^{92}{ }^{94}$ ]. Therefore, it was proposed that the catalytic activity needed for the generation of $\mathrm{Asc}^{-{ }^{-}}$and $\mathrm{H}_{2} \mathrm{O}_{2}$ in the extracellular space and interstitial fluid of the tumor may be provided by an increased abundance of metal ions found there $\left[{ }^{76}\right]$. This hypothesis would explain why Asc ${ }^{\bullet-}$ and $\mathrm{H}_{2} \mathrm{O}_{2}$ were found in sustainable concentrations in the interstitial fluids of the tumor after a single dose of pharmacologic ascorbate. Based on these considerations, the $\mathrm{H}_{2} \mathrm{O}_{2}$ generated by ascorbate oxidation in the extracellular space could accumulate to concentrations greater than found intracellularly, causing a net diffusion across the cell membrane and ultimately resulting in greater toxicity to tumor cells $\left[{ }^{16}, 83\right]$.

Using this knowledge, the Cullen laboratory began focusing on pancreatic tumor xenografts $\left[{ }^{77}\right]$. It was soon demonstrated that mice receiving pharmacological ascorbate had significantly slower tumor growth when compared to control animals. Furthermore, there was a greater than 3-fold decrease in overall tumor volume in animals receiving ascorbate when compared to controls and a log-rank analyses of survival showed that animals receiving ascorbate had significantly increased survival. All mice that entered the study completed the treatment period, with none of the animals having to be sacrificed for continued weight loss or cachexia, further supporting the hypothesis that pharmacologic ascorbate is non-toxic to normal, healthy cells and tissues. Taken together these studies strongly suggested that pharmacologic doses of ascorbate achievable in humans might have potential for therapy in pancreatic cancer.

\section{MECHANISM OF ASCORBATE INDUCED CYTOTOXICITY IN PANCREATIC CANCER}

As noted above, the administration of pharmacologic ascorbate is associated with the formation of $\mathrm{H}_{2} \mathrm{O}_{2}$ in the extracellular fluid surrounding a tumor [ $17,59,60,73,76,77,83$, 95]. In the presence of catalytic metal ions, ascorbate functions as a pro-oxidant and induces oxidative stress, but even in the absence of metals the autoxidation of ascorbate generates significant amounts of $\mathrm{H}_{2} \mathrm{O}_{2}$ when ascorbate is at millimolar concentrations [ $17,59,60$ ]. 
Since ascorbate readily oxidizes to produce $\mathrm{H}_{2} \mathrm{O}_{2}$, pharmacologic ascorbate has been proposed as a pro-drug for the delivery of $\mathrm{H}_{2} \mathrm{O}_{2}$ to tumors [ $\left.16,73,76,77,{ }^{83}\right] . \mathrm{H}_{2} \mathrm{O}_{2}$ generation is dependent on ascorbate concentration and incubation time, and has a linear relationship with ascorbate radical formation $\left[{ }^{83}\right] . \mathrm{H}_{2} \mathrm{O}_{2}$ can affect both extracellular and intracellular targets, as it is permeable across lipid membranes [ 96,97$]$. Extracellular $\mathrm{H}_{2} \mathrm{O}_{2}$ may attack membrane lipids forming lipid hydroperoxides and causing leaky membranes. Intracellularly, oxidative stress and DNA damage promote cell death, possibly via autophagy $\left[{ }^{73}, 76,77,83\right]$.

Interestingly, it has been observed that increasing intracellular levels of ascorbate does not enhance cytotoxicity. L-Ascorbate 2-phosphate (A2P) is a form of ascorbate that is protected from oxidation by the presence of a phosphate moiety. It binds to the extracellular cell surface where the phosphate group is then hydrolyzed by cell membrane associated esterases, resulting in the transport of the ascorbate into the cell [ $\left.98 \_100\right]$. The addition of A2P to cell culture media increases intracellular ascorbate to millimolar concentrations $\left.{ }^{[101}\right]$ but the addition of A2P to cells being treated with extracellular pharmacological ascorbate does not enhance the cytotoxicity in pancreatic cancer cells [ $\left.{ }^{102}\right]$. Indeed, cells treated with A2P showed no changes in clonogenic survival when compared to controls, while cells treated with ascorbate had significant decreases in clonogenic survival. Additionally, clonogenic survival was similar in cells treated with the combination of A2P and ascorbate when compared to ascorbate alone, suggesting that increases in intracellular ascorbate are not responsible for the ascorbate-induced cytotoxicity observed when ascorbate is added to the extracellular medium. These data further support the hypothesis that ascorbate-induced cytotoxicity is due to the formation of extracellular $\mathrm{H}_{2} \mathrm{O}_{2}$, which then diffuses into the cell and causes cytotoxicity as opposed to intracellular ascorbate oxidation.

Further evidence supporting the importance of $\mathrm{H}_{2} \mathrm{O}_{2}$ production in selective cancer cell cytotoxicity is offered by experiments that have investigated the neutralization of $\mathrm{H}_{2} \mathrm{O}_{2}$ by endogenous and exogenous catalase. Klingelhoeffer et al. demonstrated differential sensitivity to ascorbate and $\mathrm{H}_{2} \mathrm{O}_{2}$ by pretreatment with extracellular exogenous catalase, which was also correlated with endogenous intracellular catalase production in numerous cancer cell lines [ $\left.{ }^{103}\right]$. Sensitivity of three pancreatic cancer cell lines to pharmacologic ascorbate was reversed both by the pretreatment of cells with exogenous catalase (extracellular), as well as by overexpression of intracellular catalase by transfecting cells using adenovirus containing catalase cDNA $\left[{ }^{77}\right]$. Additionally, ascorbate toxicity has been enhanced in Ehrlich ascites carcinoma cells in vitro by treatment with the catalase inhibitor aminotriazole $\left[{ }^{104}\right]$. Taken together, these studies suggest that extracellular pharmacologic ascorbate mediates cancer cell death by $\mathrm{H}_{2} \mathrm{O}_{2}$ formation $\left[{ }^{53}\right]$.

The role of catalytic metal ions in the formation of $\mathrm{H}_{2} \mathrm{O}_{2}$ via pharmacologic ascorbate cannot be understated. In the presence of iron, ascorbate is oxidized rapidly as it reduces $\mathrm{Fe}^{3+}$ to $\mathrm{Fe}^{2+}$, which is then free to react with oxygen, producing superoxide radical $\left(\mathrm{Fe}^{2+}+\right.$ $\left.\mathrm{O}_{2} \rightarrow \mathrm{Fe}^{3+}+\mathrm{O}^{\cdot-}\right)$. Superoxide radical then dismutates into hydrogen peroxide $\left(\mathrm{O}_{2}{ }^{--}+\mathrm{O}_{2}{ }^{\cdot-}\right.$ $+2 \mathrm{H}^{+} \rightarrow \mathrm{H}_{2} \mathrm{O}_{2}+\mathrm{O}_{2}$ ), which in turn reacts with ferrous iron through the Fenton reaction producing hydroxyl radical $\left(\mathrm{Fe}^{2+}+\mathrm{H}_{2} \mathrm{O}_{2} \rightarrow \mathrm{Fe}^{3+}+\mathrm{HO}^{\circ}\right)$. The presence of ascorbate can 
allow the recycling of $\mathrm{Fe}^{3+}$ to $\mathrm{Fe}^{2+}$, which in turn will catalyze the formation of highly reactive oxidants from $\mathrm{H}_{2} \mathrm{O}_{2}\left[{ }^{16}\right]$.

The quantity and availability of catalytic metal ions may also play a significant role in ascorbate-induced toxicity. Normally, iron is not free in solution but is sequestered by iron binding proteins such as transferrin and ferritin [ $\left.{ }^{105}, 106\right]$. Transferrin is the major iron transport protein, moving iron absorbed in the diet from enterocytes to the cell surface where it binds to transferrin receptor, promoting endocytosis and internalization of the protein. Once intracellular, the iron is released from transferrin where it is bound to ferritin, the iron storage protein. In pathological states, such as thalassemia and hemochromatosis, free iron is found in the plasma and extracellular fluid. Chronic inflammatory diseases are also associated with increased oxidative stress and levels of catalytic metal ions in tissues. For example, increased deposition of iron protein has been demonstrated in the synovial membranes in patients with rheumatoid arthritis [ ${ }^{107},{ }^{108}$ ]. Additionally, septic patients have been found to have increased catalytic iron levels [ ${ }^{109}$ ]. In these situations the administration of ascorbate without an iron chelator could potentially lead to extensive oxidative tissue damage, similar to what is observed in ischemia/reperfusion injury [ ${ }^{17}, 110$, ${ }^{111}$ ]. Elevated serum levels of ferritin also occur in various malignancies [ $\left.112 \_114\right]$. Tumor vessels have increased permeability compared to normal endothelium, permitting the accumulation of macromolecules such as protein into the interstitial fluid $[90,91]$. As discussed above, the presence of extracellular metal-containing proteins is thought to be essential for the pro-oxidant effects of ascorbate [ ${ }^{59}, 83$ ]. Given the increase in ferritin in cancer, and the potential for its extracellular accumulation, iron-saturated ferritin may be the source of catalytic iron required for the selective ascorbate-induced cytotoxicity observed in pancreatic and other cancers $\left[{ }^{16}\right]$. Indeed, ferritin staining was detected in the stroma surrounding the neoplastic cells of breast cancer tissue $\left[{ }^{115}\right]$, and serum ferritin levels have been shown to correlate to the tumor stage and volume in cervical cancer [ $\left.{ }^{116}\right]$. Furthermore, iron can be released from ferritin by biological reductants, including ascorbate $\left[{ }^{67}\right]$ and increased ferritin may provide a continuous source of catalytic iron required for pharmacologic ascorbate-mediated $\mathrm{H}_{2} \mathrm{O}_{2}$ production and cytotoxicity.

The differential toxicity of pharmacological ascorbate between cancerous and normal cells may be due to a combination of low levels of antioxidant enzymes and high levels of endogenous ROS in cancer cells [ $\left.16,80 \_82\right]$. Additionally, erythrocytes may act as a sink for Asc ${ }^{-}$and especially $\mathrm{H}_{2} \mathrm{O}_{2}$ due to their redundant $\mathrm{H}_{2} \mathrm{O}_{2}$ catabolic pathways relative to the extracellular fluid, preventing peroxide buildup in the blood and delivery to healthy tissues, while ensuring $\mathrm{H}_{2} \mathrm{O}_{2}$ delivery to the extracellular milieu. However, the selective toxicity of ascorbate still needs to be clarified and at this time the real reasons for the selectivity are not clear.

\section{ENHANCEMENT OF ASCORBATE-INDUCED CYTOTOXICITY IN PANCREATIC CANCER}

Catalytic metals are known to increase the rate of ascorbate-induced $\mathrm{H}_{2} \mathrm{O}_{2}$ formation and, potentially, oxidative stress-mediated cytotoxicity. Porphyrin-based superoxide dismutase 
(SOD) mimetics contain a catalytic redox-active metal $(\mathrm{Mn}, \mathrm{Fe}$, or $\mathrm{Cu}$ ) coordinated within a stable porphyrin ring. In the presence of a reducing agent such as ascorbate, manganese porphyrins function as superoxide reductases rather than dismutases, with $\mathrm{Mn}$ (III) reduced to $\mathrm{Mn}$ (II) by ascorbate, allowing $\mathrm{Mn}$ (II) to react with $\mathrm{O}_{2}$ forming superoxide, which can then form $\mathrm{H}_{2} \mathrm{O}_{2}\left[{ }^{16}\right]$. Several studies have demonstrated enhanced ascorbate oxidation using manganese porphyrins in vitro, with synergistic killing of pancreatic cancer cell lines vs. pharmacologic ascorbate alone $\left[{ }^{117}, 118\right]$. In addition, manganese porphyrins have already been tested alone in vivo and have minimal toxicity even at increased doses [ $\left.{ }^{119}\right]$. Thus, porphyrins could be used as adjuvants to enhance the efficacy of pharmacologic ascorbate in the treatment of pancreatic cancer.

Oxidative stress has also been shown to increase the levels of catalytic iron in tissues along with ionizing radiation and some chemotherapeutic drugs [120_122]. Thus, combination therapies, such as chemotherapy plus pharmacologic ascorbate, and radiation therapy plus pharmacologic ascorbate may act synergistically to potentiate ascorbate-induced cytotoxicity. To test for synergism between chemotherapy and ascorbate, Espey and colleagues demonstrated that pharmacologic ascorbate in combination with gemcitabine, the standard of care chemotherapeutic in pancreatic cancer, significantly enhanced gemcitabine cytotoxicity [ $\left.{ }^{123}\right]$. Furthermore, as the ratio of ascorbate to gemcitabine was increased, cytotoxicity increased proportionally, suggesting that when used in combination, a lower gemcitabine dose could be used to obtain the same antitumor activity $\left[{ }^{53}\right]$. Finally, treatment of pancreatic cancer xenografts with the ascorbate + gemcitabine combination in vivo resulted in significant inhibition of tumor growth vs. ascorbate or gemcitabine alone. Thus, pharmacologic ascorbate synergizes with gemcitabine to improve therapeutic efficacy.

As previously discussed, the cytotoxicity of pharmacologic ascorbate is directly related to the production of $\mathrm{H}_{2} \mathrm{O}_{2}$ in the extracellular space, and its flux into cancer cells, resulting in oxidative stress, DNA damage, and ultimately cell death. In a recent study, Olney et al. proposed that inhibiting intracellular hydroperoxide removal during the administration of pharmacologic ascorbate would increase the cytotoxicity observed in pancreatic cancer cells $\left[{ }^{102}\right]$. Human pancreatic cancer cells were treated with ascorbate alone or in combination with intracellular inhibitors of $\mathrm{H}_{2} \mathrm{O}_{2}$ removal, including the glutathione disulfide reductase inhibitor 1,3 bis (2-chloroethyl)-1-nitrosurea (BCNU), siRNA targeted to glutathione disulfide reductase (siGR), and an inhibitor of glucose metabolism, 2-deoxy-D-glucose (2DG). Also, endogenous catalase (removal of $\mathrm{H}_{2} \mathrm{O}_{2}$ via reduction to water) activity was inhibited using aminotriazole so that ascorbate-induced changes in intracellular $\mathrm{H}_{2} \mathrm{O}_{2}$ could be determined (Fig. 2).

BCNU is a clinically used chemotherapeutic agent that causes DNA alkylation but is also known to inhibit glutathione disulfide reductase (GR). With GR inhibited, cells have a reduced ability to remove $\mathrm{H}_{2} \mathrm{O}_{2}$ via the glutathione peroxidase system. 2DG is a glucose analog and a competitive inhibitor for uptake via the glucose transporters. Competition between 2DG and glucose is thought to cause inhibition of glucose metabolism, thereby creating a chemically induced state of glucose deprivation resulting in inhibition of hydroperoxide detoxification [ ${ }^{79}$ ]. Likewise, knockdown of endogenous GR protein levels using siRNA could also prevent $\mathrm{H}_{2} \mathrm{O}_{2}$ via the glutathione peroxidase system. 
When inhibitors of peroxide removal were added to pharmacological ascorbate, both ascorbate-induced cytotoxicity, and intracellular $\mathrm{H}_{2} \mathrm{O}_{2}$ concentrations were increased. The combination of BCNU and ascorbate dramatically decreased clonogenic survival, while genetically inhibiting GR levels by $>50 \%$ also decreased clonogenic survival. Finally, using the glucose analog 2DG, experiments demonstrated that combination treatment with 2DG and ascorbate enhanced cytotoxicity with decreased clonogenic survival and cell viability in pancreatic cancer cell lines [ $\left.{ }^{102}\right]$. Endogenous catalase activity inhibition with aminotriazole significantly increased intracellular $\mathrm{H}_{2} \mathrm{O}_{2}$ concentrations using all three methodologies of inhibiting hydroperoxide removal discussed above. Together these data demonstrate that inhibitors of $\mathrm{H}_{2} \mathrm{O}_{2}$ removal enhance both ascorbate-induced intracellular steady-state concentrations of $\mathrm{H}_{2} \mathrm{O}_{2}$ and cytotoxicity. Thus, treatments consisting of a combination of ascorbate and inhibitors of the removal of $\mathrm{H}_{2} \mathrm{O}_{2}$ may potentially be an effective therapy for pancreatic adenocarcinoma.

\section{PHASE I CLINICAL TRIALS OF PHARMACOLOGICAL ASCORBATE}

Theoretically pharmacological ascorbate should be safe in patients. However, given that ascorbate acts as a pro-drug for the delivery of $\mathrm{H}_{2} \mathrm{O}_{2}$, there is a risk that at high concentrations, it could potentially induce intravascular hemolysis in patients with glucose-6-phosphate dehydrogenase (G6PD) deficiency that cannot efficiently regenerate glutathione (Fig. 1) [124_126]. Additionally, in patients with pre-existing renal insufficiency or nephrolithiasis, there is a risk of forming calcium oxalate crystals within the urinary space, as oxalic acid is one of the end products of ascorbate oxidation $\left[{ }^{127}\right]$. Furthermore, because of the rapid oxidation of ascorbate into $\mathrm{H}_{2} \mathrm{O}_{2}$ by catalytic metals, the administration of pharmacologic ascorbate to individuals with iron overload (hemochromatosis, thalassemia, and other conditions requiring multiple transfusions) is likely contraindicated $\left[{ }^{71},{ }^{128}\right]$. In the early trials of Cameron and Campbell, there were also rare cases of massive tumor hemorrhage reported after the administration of high-dose ascorbate in patients with advanced cancers $\left[{ }^{64},{ }^{129}\right]$. At this time, several Phase I clinical trials of intravenous ascorbate in patients with advanced cancers have been performed $\left[{ }^{74}, 130 \_133\right]$. The main focus of these initial trials has been pharmacokinetics, dosing, resulting ascorbate plasma concentrations, and safety. In addition, some trials have also examined the clinical consequences of the pharmacologic ascorbate therapy.

In 2004, Riordan et al. published case reports of patients with renal cell carcinoma, breast cancer, pancreatic cancer and lymphoma in which I.V. ascorbate was administered in doses of 10 to $100 \mathrm{grams} /$ day, up to three times per week, with improved patient well-being, and in some cases reduced tumor size, with minimal toxicity [ $\left.{ }^{134}\right]$. Based on these reports, Riordan and colleagues performed a phase I clinical trial the following year in which 24 late stage terminal cancer patients were given continuous infusions of ascorbate at doses of 150 to 710 $\mathrm{mg} / \mathrm{kg} /$ day for up to eight weeks $\left[{ }^{131}\right]$. During therapy, serum ascorbate concentrations ranged from 0.28 to $3.8 \mathrm{mM}$. The most commonly reported adverse events during the study were minor and included nausea, dry mouth, dry skin and minor edema. Grade 3 adverse events were minor and few, demonstrating that pharmacological ascorbate was welltolerated with caution in patients with a history of nephrolithiasis. 
Later, Hoffer and colleagues performed a phase I dose-escalating and pharmacokinetic study of intravenous ascorbate in patients with advanced malignancies with the primary objective of determining a recommended dosage for phase II trials, and secondary objectives of determining adverse effects, anti-tumor effects, and patient quality of life during treatment $\left.{ }^{74}\right]$. Ascorbate was administered three times per week at fixed doses of 0.4, 0.6, 0.9, and $1.5 \mathrm{~g} / \mathrm{kg}$. During therapy, serum ascorbate concentrations ranged from 2.4 to $26 \mathrm{mM}$, and at the highest dosage $(1.5 \mathrm{~g} / \mathrm{kg})$ pharmacokinetic studies determined that plasma ascorbate concentrations exceeding $10 \mathrm{mM}$ were achievable for approximately 4.5 hours; levels that are known to induce cytotoxicity in a variety of cancer cells $\left[{ }^{73}, 76,77\right.$ ]. Adverse effects reported were mild and were consistent with the side effects expected from the rapid infusion of any high osmolarity solution. The symptoms were preventable by encouraging patients to drink fluids before and during the infusion. No unusual biochemical or hematologic abnormalities were observed during the study, and patients whose ascorbate dose was $\geq 0.6 \mathrm{~g} / \mathrm{kg}$ maintained their physical quality of life throughout the trial, whereas those at the lowest dose did not. None of the patients were found to have objective tumor responses to the treatment, and all patients eventually experienced disease progression. The authors recommended $1.5 \mathrm{~g} / \mathrm{kg}$ as the starting dose for future phase II trials and concluded that ascorbate might need to be combined with cytotoxic or other redox-active molecules to be an efficacious treatment $\left[{ }^{74}\right]$.

Pharmacological ascorbate may also affect quality of life in cancer patients [ ${ }^{133}$ ]. In 60 patients with various newly diagnosed malignant cancers who were receiving adjuvant intravenous ascorbate, quality of life was assessed before beginning treatment, and then at weeks 2 and 4 of therapy [135_137]. In this study, patients received pharmacologic ascorbate in biweekly infusions, with target blood ascorbate concentrations of 350-400 $\mathrm{mg} / \mathrm{dL}$ immediately following infusion $\left[{ }^{138}\right]$. The study did not address peak plasma ascorbate levels or clinical disease progression. Interestingly, the QOL scores significantly improved at both 2 weeks $(\mathrm{p}<0.05)$ and 4 weeks $(\mathrm{p}<0.01)$ of treatment, compared to initial scores. Patients also showed significant increases in physical, emotional, cognitive and social functioning after 4 weeks of I.V. ascorbate therapy. Furthermore, patients showed significant relief of fatigue, pain, insomnia, constipation and financial difficulties scores. Nearly half of the patients at two weeks and $60 \%$ of their patients at four weeks had minimally or much improved quality of life. At the conclusion of their study, the authors proposed that pharmacologic ascorbate can safely improve the quality of life of cancer patients, and suggested its further use as a palliative care therapy, focusing on improving quality of life, and in particular, relief from fatigue.

Recently, Stephenson et al., completed another phase I trial to evaluate the safety, tolerability, and pharmacokinetics of high dose pharmacologic ascorbate as a monotherapy in patients with advanced cancers that were refractory to standard therapy $\left[{ }^{132}\right]$. If the relatively poor anticancer response observed in the prior phase I studies with ascorbate was due to inadequate concentrations of ascorbate achieved within the systemic compartment, or failure to achieve the adequate duration of elevated concentration necessary for cytotoxicity then higher blood levels, longer exposure times, and higher dose intensity should increase both toxicity and antitumor efficacy. In the study, five cohorts of three patients received intravenous ascorbate for 4 consecutive days per week, for 4 weeks. The ascorbate was 
administered at $1 \mathrm{~g} / \mathrm{min}$ starting at a total dose of $30 \mathrm{~g} / \mathrm{m}^{2}$ in the first cohort with subsequent cohorts having the dose increased by $20 \mathrm{~g} / \mathrm{m}^{2}$ until a maximum tolerated dose was found. Dose-limiting toxicity (DLT), defined as any reversible adverse event $\geq$ grade 3 was monitored. If a DLT was observed in $\geq 2$ patients, then the maximum tolerated dose (MTD) would be defined as the dose just below the dose at which the DLT was observed. Data were obtained for cohorts treated with $30,50,70,90$, and $110 \mathrm{~g} / \mathrm{m}^{2}$.

Pharmacokinetics showed that ascorbate was eliminated by simple first-order kinetics and did not accumulate to any significant level during consecutive daily administrations. The half-life and clearance rate values of ascorbate were similar for all patients across all the cohorts. The maximum plasma concentration increased proportionately with increasing ascorbate doses before maxing out at $70 \mathrm{~g} / \mathrm{m}^{2}$. Each of the three highest doses maintained plasma ascorbate levels between 10-20 $\mathrm{mM}$ for 5-6 hours. Even at the higher doses, intravenous ascorbate was well tolerated, again with the most common side effects being headache and nausea. None of the patients experienced any objective tumor response with 3 patients having stable disease and the rest with tumor progression. Collectively, the studies discussed above have demonstrated that pharmacologic ascorbate is safe and well tolerated. The relatively mild side effects related to its administration are thought to be due to its high osmolality and include nausea, vomiting, headache, dry mouth, flushing, diarrhea and minor edema $\left[{ }^{74}, 130 \_132\right.$ ]. These symptoms were widely preventable by encouraging patients to drink fluids before and during the infusion $\left[{ }^{74}\right]$. In addition, pharmacologic ascorbate may improve quality of life and relieve certain symptoms related to cancer burden, including fatigue $\left[{ }^{133}\right]$. The one major side effect directly attributable to pharmacologic ascorbate seems to be the risk of subsequent kidney stone formation in patients with prior history of stones $\left[{ }^{131}\right.$ ]. Importantly plasma ascorbate concentrations up to $49 \mathrm{mM}$ are attainable and levels of 10-20 mM are sustainable for 5-6 hours.

\section{CLINICAL TRIALS OF PHARMACOLOGICAL ASCORBATE IN THE TREATMENT OF PANCREATIC CANCER}

In 2012, Monti et al. published the results of a phase I clinical trial specifically aimed at examining the safety and efficacy of intravenous ascorbate in the treatment of patients with metastatic stage IV pancreatic ductal adenocarcinoma $\left[{ }^{130}\right]$. Fourteen patients were enrolled to receive intravenous ascorbate of 50,75, or 100 grams three times per week for 8 weeks, combined with the standard of care chemotherapy gemcitabine and erlotinib. The primary aim of the trial was assessing safety with a secondary aim of assessing response to treatment. Out of 14 patients who enrolled in the study, 9 patients completed the treatment. Two subjects chose to discontinue the study because it was too difficult for them to come into the hospital for treatments, and three subjects died from rapid disease progression before completing therapy. Adverse events including nausea and mild lightheadedness and serious adverse events were attributable to chemotherapy or progression of disease. In patients receiving 100 grams of ascorbate, peak plasma levels of between 25 to $32 \mathrm{mM}$ were reported. At the end of the study, 8 out of 9 patients who completed 8 weeks of treatments had reduction in the size of their primary tumor, and one patient's tumor was stable in size. By RECIST criteria, 7 patients had stable disease and 2 patients had progressive disease 
$\left.{ }^{139}\right]$. Progression-free survival time was similar to previously reported data from patients treated with gemcitabine/erlotinib alone. Most importantly, this study demonstrated that there was no increased toxicity when pharmacologic ascorbate was added to gemcitabine and erlotinib treatments in patients with metastatic pancreatic cancer.

More recently in 2013, the University of Iowa group completed a phase I clinical trial examining the toxicity and efficacy of pharmacological ascorbate combined with gemcitabine in patients with stage IV pancreatic adenocarcinoma $\left[{ }^{140}\right]$. Fourteen subjects were enrolled to receive 15-125 g of ascorbate per infusion, twice weekly for 4 week cycles. The dose of ascorbate escalated each week and was tailored to each patient to achieve plasma ascorbate concentrations of $\geq 20 \mathrm{mM}$, In addition, each patient received gemcitabine once weekly for 3 weeks followed by one week of rest. Ascorbate treatments cycles continued until a patient experienced a $\geq$ grade 3 dose limiting toxicity or until disease progression, as defined by the RECIST criteria $\left[{ }^{139}\right]$. Nine subjects completed at least two cycles of treatment. No dose limiting toxicities or serious adverse effects attributable to intravenous ascorbate occurred during the study. The most common side effects reported were nausea, diarrhea and dry mouth. Pharmacologically, plasma ascorbate levels ranged from 20 to $25 \mathrm{mM}$ in the first hour post-infusion, and mean trough levels remained significantly elevated compared to baseline levels in all subjects. Asc ${ }^{--}$was measured in pre and post-infusion blood samples, and was only detectable during pharmacological levels of ascorbate, consistent with a greatly increased rate of ascorbate oxidation $\left[{ }^{141}\right]$. Additionally, $F_{2}$-isoprostane levels, a marker of systemic oxidative stress [ ${ }^{142}$ ], decreased after ascorbate infusions, suggesting that ascorbate does not induce systemic oxidative stress but may act as an antioxidant systemically while simultaneously acting as a pro-oxidant at the tumor. Twothirds of the patients improved their overall performance status, while the mean time to disease progression was $26 \pm 7$ weeks. As of August 2014 mean overall survival was $15 \pm 2$ months, a significant improvement compared to trials of gemcitabine alone for advanced pancreatic cancer (mean progression free survival and mean overall survival of 9 weeks and 6 months, respectively) (Fig. 3) $\left[{ }^{13}\right]$. This study again demonstrated that the use of pharmacological ascorbate in combination with gemcitabine is safe and well tolerated. Combined, these studies provide a strong justification for the establishment of a phase II clinical trial sufficiently powered to determine the efficacy of pharmacological ascorbate combined with gemcitabine.

\section{PHARMACOLOGICAL ASCORBATE AS AN ADJUVANT TO RADIOTHERAPY}

For the majority of patients with pancreatic cancer, adjuvant chemotherapy and radiotherapy remain the only treatment option with the goal of palliating symptoms and improving quality of life [ ${ }^{12}$ ]. Radiation has been shown to increase the levels of catalytic iron in tissues, which increases the rate of ascorbate-induced peroxide formation and cytotoxicity $\left[{ }^{17},{ }^{121}\right]$. The sensitivity of glioblastoma multiforme cells to radiation was enhanced by exposure to pharmacological ascorbate $\left[{ }^{143}\right]$. Combination treatment was shown to increase the number of double stranded DNA breaks relative to that produced by radiation alone. Similar findings were demonstrated in the human leukemia cell line, HL60 [ $\left.{ }^{144}\right]$. Therefore, investigation into whether pharmacologic ascorbate may acts as synergistically with radiation therapy to increase radiation-induced pancreatic cancer cell death is of interest. 


\section{CONCLUSIONS}

It has been over fifty years since ascorbate was described as a potential therapy for cancer. Parenteral ascorbate first demonstrated clinical benefit in the treatment of cancer in the early trials of Cameron, Pauling, and Campbell in the 1970s. Randomized, double-blinded clinical trials at the Mayo Clinic utilizing orally administered ascorbate; neither study showed any benefit and ascorbate was dismissed as a potential chemotherapeutic agent in the treatment of cancer by the research and medical communities. Till recently, that studies showed that oral and intravenous ascorbate have strikingly different pharmacokinetic properties and that the bioavailability of orally administered ascorbate is much lower than when administered intravenously. Clinical data show that when ascorbate is given orally, fasting plasma concentrations are tightly controlled at $<100 \mu \mathrm{mol} / \mathrm{L}$. However we now know that intravenous doses of $\sim 80 \mathrm{~g} / \mathrm{m}^{2}$ are able to achieve plasma concentrations of up to $49 \mathrm{mmol}$ Thus, interest into the clinical potential of pharmacological ascorbate in the treatment of cancer was rekindled. Interestingly, at pharmacologic concentrations and in the presence of catalytic metal ions, ascorbate functions as a pro-oxidant and can induce oxidative stress via the generation of extracellular $\mathrm{H}_{2} \mathrm{O}_{2}$.

The selective cytotoxicity of pharmacologic ascorbate to tumor cells has been confirmed in several cancer cell lines in both in vitro and in vivo models in several laboratories. Several phase I trials have demonstrated that pharmacological ascorbate is safe and well tolerated, with mild side effects and possible improvement in quality of life during treatment. Two recent phase I clinical trials investigating the safety and efficacy of pharmacologic ascorbate in combination with gemcitabine chemotherapy in the treatment of stage IV pancreatic adenocarcinoma demonstrated safety without increased toxicity, with promising and possible efficacy.

\section{Acknowledgments}

Supported by NIH grants U01166800, R01 CA169046, P30 CA086862, P42 ES013661, CA111365, and T32 CA148062, the Medical Research Service, and the Department of Veterans Affairs 1I01BX001318-01A2.

\section{References}

1. Jemal A, Siegel R, Ward E, Hao Y, Xu J, Thun MJ. Cancer statistics, CA: a cancer journal for clinicians. 2009; 59:225-249. [PubMed: 19474385]

2. Howlader, NNA.; Krapacho, M.; Garshell, J.; Neyman, N.; Altekruse, SF.; Kosary, CL.; Yu, M.; Ruhl, J.; Tatalovich, Z.; Cho, H.; Mariotto, A.; Lewis, DR.; Chen, HS.; Feuer, EJ.; Cronin, KA. In: Howlader, NNA.; Krapacho, M.; Garshell, J.; Neyman, N.; Altekruse, SF.; Kosary, CL.; Yu, M.; Ruhl, J.; Tatalovich, Z.; Cho, H.; Mariotto, A.; Lewis, DR.; Chen, HS.; Feuer, EJ.; Cronin, KA., editors. SEER Cancer Statistics Review; Based on November 2012 SEER data submission, posted to the SEER web site; April 2013; Bethesda, MD: National Cancer Institute; Apr. 2013

3. Bramhall SR, Allum WH, Jones AG, Allwood A, Cummins C, Neoptolemos JP. Treatment and survival in 13,560 patients with pancreatic cancer, and incidence of the disease, in the West Midlands: an epidemiological study. Brit J Surg. 1995; 82:111-115. [PubMed: 7881926]

4. Yeo CJ, Cameron JL. Pancreatic cancer. Curr Probl Surg. 1999; 36:59-152. [PubMed: 10021685]

5. Winstead, E. NCI Cancer Bulletin. Vol. 6. National Cancer Institute; Bethesda, MD: Nov. 1999 Pancreatic Cancer Report Urges Changes in Clinical Trials.

6. Porta M, Fabregat X, Malats N, Guarner L, Carrato A, de Miguel A, Ruiz L, Jariod M, Costafreda S, Coll S, Alguacil J, Corominas JM, Solà R, Salas A, Real FX. Exocrine pancreatic cancer: symptoms 
at presentation and their relation to tumour site and stage. Clin Translat Oncol: Off Public Federat Span Oncol Soc Nat Canc Inst Mex. 2005; 7:189-197.

7. Bakkevold KE, Kambestad B. Long-term survival following radical and palliative treatment of patients with carcinoma of the pancreas and papilla of Vater-the prognostic factors influencing the long-term results. A prospective multicentre study. Eur J Surgic Oncol : J Eur Soc Surgic Oncol Brit Assoc Surgic Oncol. 1993; 19:147-161.

8. Geer RJ, Brennan MF. Prognostic indicators for survival after resection of pancreatic adenocarcinoma. Am J Surg. 1993; 165:68-72. discussion -3. [PubMed: 8380315]

9. Trede M, Schwall G, Saeger HD. Survival after pancreatoduodenectomy. 118 consecutive resections without an operative mortality. Annals Surg. 1990; 211:447-458.

10. Yeo CJ, Cameron JL, Lillemoe KD, Sitzmann JV, Hruban RH, Goodman SN, Dooley WC, Coleman J, Pitt HA. Pancreaticoduodenectomy for cancer of the head of the pancreas. 201 patients. Annals Surg. 1995; 221:721-731. discussion 31-3.

11. Ghaneh P, Costello E, Neoptolemos JP. Biology and management of pancreatic cancer. Gut. 2007; 56:1134-1152. [PubMed: 17625148]

12. Di Marco M, Di Cicilia R, Macchini M, Nobili E, Vecchiarelli S, Brandi G, Biasco G. Metastatic pancreatic cancer: is gemcitabine still the best standard treatment? (Review). Oncol Reports. 2010; 23:1183-1192.

13. Burris HA 3rd, Moore MJ, Andersen J, Green MR, Rothenberg ML, Modiano MR, Cripps MC, Portenoy RK, Storniolo AM, Tarassoff P, Nelson R, Dorr FA, Stephens CD, Von Hoff DD. Improvements in survival and clinical benefit with gemcitabine as first-line therapy for patients with advanced pancreas cancer: a randomized trial. J Clinic Oncol : Off J Am Soc Clinic Oncol. 1997; 15:2403-2413.

14. Conroy T, Desseigne F, Ychou M, Bouche O, Guimbaud R, Becouarn Y, Adenis A, Raoul JL, Gourgou-Bourgade S, de la Fouchardière C, Bennouna J, Bachet JB, Khemissa-Akouz F, PéréVergé D, Delbaldo C, Assenat E, Chauffert B, Michel P, Montoto-Grillot C, Ducreux M, Groupe Tumeurs Digestives of Unicancer; PRODIGE Intergroup. FOLFIRINOX versus gemcitabine for metastatic pancreatic cancer. New Eng J Med. 2011; 364:1817-1825. [PubMed: 21561347]

15. Ghaneh P, Neoptolemos J. Adjuvant chemotherapy - the standard after resection for pancreatic cancer. Am J Surg. 2007; 194:S131-S7.

16. Du J, Cullen JJ, Buettner GR. Ascorbic acid: chemistry, biology and the treatment of cancer. Biochim Biophys Acta. 2012; 1826:443-457. [PubMed: 22728050]

17. Buettner GR, Jurkiewicz BA. Catalytic metals, ascorbate and free radicals: combinations to avoid. Radiat Res. 1996; 145:532-541. [PubMed: 8619018]

18. Williams NH, Yandell JK. Outer-Sphere electron-transfer reactions of ascorbate anions. Aust J Chem. 1982; 35:1133-1144.

19. Levine M, Wang Y, Padayatty SJ, Morrow J. A new recommended dietary allowance of vitamin C for healthy young women. Proceed Nat Acad Sci USA. 2001; 98:9842-9846.

20. Lloyd JV, Davis PS, Emery H, Lander H. Platelet ascorbic acid levels in normal subjects and in disease. J Clin Pathol. 1972; 25:478-483. [PubMed: 4504974]

21. Evans RM, Currie L, Campbell A. The distribution of ascorbic acid between various cellular components of blood, in normal individuals, and its relation to the plasma concentration. Brit $\mathrm{J}$ Nutrit. 1982; 47:473-482. [PubMed: 7082619]

22. Li H, Tu H, Wang Y, Levine M. Vitamin C in mouse and human red blood cells: an HPLC assay. Analyt Biochem. 2012; 426:109-117. [PubMed: 22522059]

23. Lane DJ, Lawen A. Ascorbate and plasma membrane electron transport-enzymes vs efflux. Free Radical Biol Med. 2009; 47:485-495. [PubMed: 19501649]

24. Wilson JX. Antioxidant defense of the brain: a role for astrocytes. Can J Physiol Pharmacol. 1997; 75:1149-1163. [PubMed: 9431439]

25. Brubaker RF, Bourne WM, Bachman LA, McLaren JW. Ascorbic acid content of human corneal epithelium. Investig Ophthalmol Visual Sci. 2000; 41:1681-1683. [PubMed: 10845585]

26. Kern HL, Zolot SL. Transport of vitamin C in the lens. Curr Eye Res. 1987; 6:885-896. [PubMed: 3621982] 
27. Hornig D. Distribution of ascorbic acid, metabolites and analogues in man and animals. Annals NY Acad Sci. 1975; 258:103-118.

28. Rumsey SC, Levine M. Absorption, transport, and disposition of ascorbic acid in humans. J Nutr Biochem. 1998; 9:116-130.

29. Streeter ML, Rosso P. Transport mechanisms for ascorbic acid in the human placenta. Am J Clin Nutr. 1981; 34:1706-1711. [PubMed: 7282597]

30. Ozer A, Bruick RK. Non-heme dioxygenases: cellular sensors and regulators jelly rolled into one? Nat Chem Biol. 2007; 3:144-153. [PubMed: 17301803]

31. Englard S, Seifter S. The biochemical functions of ascorbic acid. Ann Rev Nutr. 1986; 6:365-406. [PubMed: 3015170]

32. Kivirikko KI, Prockop DJ. Enzymatic hydroxylation of proline and lysine in protocollagen. Proceed Nation Acad Sci USA. 1967; 57:782-789.

33. Myllyharju J, Kivirikko KI. Collagens, modifying enzymes and their mutations in humans, flies and worms. Trends Genet : TIG. 2004; 20:33-43. [PubMed: 14698617]

34. Bruick RK, McKnight SL. A conserved family of prolyl-4-hydroxylases that modify HIF. Science. 2001; 294:1337-1340. [PubMed: 11598268]

35. Mole DR, Blancher C, Copley RR, Pollard PJ, Gleadle JM, Ragoussis J, Ratcliffe PJ. Genomewide association of hypoxia-inducible factor (HIF)-1alpha and HIF-2alpha DNA binding with expression profiling of hypoxia-inducible transcripts. J Biol Chem. 2009; 284:16767-16775. [PubMed: 19386601]

36. Semenza GL. Targeting HIF-1 for cancer therapy. Nat Rev Canc. 2003; 3:721-732.

37. Semenza GL. Hypoxia-inducible factors: mediators of cancer progression and targets for cancer therapy. Trends Pharmacol Sci. 2012; 33:207-214. [PubMed: 22398146]

38. Chung TL, Brena RM, Kolle G, Grimmond SM, Berman BP, Laird PW, Pera MF, Wolvetang EJ. Vitamin C promotes widespread yet specific DNA demethylation of the epigenome in human embryonic stem cells. Stem Cells. 2010; 28:1848-1855. [PubMed: 20687155]

39. Cloos PA, Christensen J, Agger K, Helin K. Erasing the methyl mark: histone demethylases at the center of cellular differentiation and disease. Genes Developm. 2008; 22:1115-1140.

40. Cyr AR, Domann FE. The redox basis of epigenetic modifications: from mechanisms to functional consequences. Antioxid Redox Signal. 2011; 15:551-589. [PubMed: 20919933]

41. Esteban MA, Pei D. Vitamin C improves the quality of somatic cell reprogramming. Nat Genet. 2012; 44:366-367. [PubMed: 22456737]

42. Nishikimi M, Fukuyama R, Minoshima S, Shimizu N, Yagi K. Cloning and chromosomal mapping of the human nonfunctional gene for L-gulono-gamma-lactone oxidase, the enzyme for L-ascorbic acid biosynthesis missing in man. J Biol Chem. 1994; 269:13685-13688. [PubMed: 8175804]

43. Diliberto EJ Jr, Heckman GD, Daniels AJ. Characterization of ascorbic acid transport by adrenomedullary chromaffin cells. Evidence for Na+-dependent co-transport. The Journal of biological chemistry. 1983; 258:12886-94. [PubMed: 6630211]

44. Savini I, Rossi A, Pierro C, Avigliano L, Catani MV. SVCT1 and SVCT2: key proteins for vitamin C uptake. Amino Acids. 2008; 34:347-355. [PubMed: 17541511]

45. Vera JC, Rivas CI, Velasquez FV, Zhang RH, Concha II, Golde DW. Resolution of the facilitated transport of dehydroascorbic acid from its intracellular accumulation as ascorbic acid. J Biol Chem. 1995; 270:23706-23712. [PubMed: 7559541]

46. Welch RW, Bergsten P, Butler JD, Levine M. Ascorbic acid accumulation and transport in human fibroblasts. Biochem J. 1993; 294(Pt 2):505-510. [PubMed: 8373364]

47. Corpe CP, Tu H, Eck P, Wang J, Faulhaber-Walter R, Schnermann J, Margolis S, Padayatty S, Sun H, Wang Y, Nussbaum RL, Espey MG, Levine M. Vitamin C transporter Slc23a1 links renal reabsorption, vitamin $\mathrm{C}$ tissue accumulation, and perinatal survival in mice. J Clin Investig. 2010; 120:1069-1083. [PubMed: 20200446]

48. Tsukaguchi H, Tokui T, Mackenzie B, Berger UV, Chen XZ, Wang Y, Brubaker RF, Hediger MA. A family of mammalian Na+-dependent L-ascorbic acid transporters. Nature. 1999; 399:70-75. [PubMed: 10331392] 
49. MacDonald L, Thumser AE, Sharp P. Decreased expression of the vitamin C transporter SVCT1 by ascorbic acid in a human intestinal epithelial cell line. Brit J Nutr. 2002; 87:97-100. [PubMed: 11895172]

50. Padayatty SJ, Sun H, Wang Y, Riordan HD, Hewitt SM, Katz A, Wesley RA, Levine M. Vitamin C pharmacokinetics: implications for oral and intravenous use. Annals Inter Med. 2004; 140:533537.

51. Savini I, Catani MV, Arnone R, Rossi A, Frega G, Del Principe D, Avigliano L. Translational control of the ascorbic acid transporter SVCT2 in human platelets. Free Radical Biol Med. 2007; 42:608-616. [PubMed: 17291984]

52. Graumlich JF, Ludden TM, Conry-Cantilena C, Cantilena LR Jr, Wang Y, Levine M. Pharmacokinetic model of ascorbic acid in healthy male volunteers during depletion and repletion. Pharmaceut Res. 1997; 14:1133-1139.

53. Parrow NL, Leshin JA, Levine M. Parenteral Ascorbate As a Cancer Therapeutic: A Reassessment Based on Pharmacokinetics. Antioxid Redox Signal. 2013

54. Buettner GR. The pecking order of free radicals and antioxidants: lipid peroxidation, alphatocopherol, and ascorbate. Arch Biochem Biophys. 1993; 300:535-543. [PubMed: 8434935]

55. Burton GW, Ingold KU. Vitamin-E - application of the principles of physical organic-chemistry to the exploration of its structure and function. Accounts Chem Res. 1986; 19:194-201.

56. Golumbic C, Mattill HA. Antioxidants and the autoxidation of fats. XIII. The antioxygenic action of ascorbic acid in association with tocopherols, hydroquinones and related compounds. J Am Chem Soc. 1941; 63:1279-1280.

57. Suh J, Zhu BZ, Frei B. Ascorbate does not act as a pro-oxidant towards lipids and proteins in human plasma exposed to redox-active transition metal ions and hydrogen peroxide. Free Radical Biol Med. 2003; 34:1306-1314. [PubMed: 12726918]

58. Linster CL, Van Schaftingen E. Vitamin C. Biosynthesis, recycling and degradation in mammals. FEBS J. 2007; 274:1-22. [PubMed: 17222174]

59. Frei B, Lawson S. Vitamin C and cancer revisited. Proceed Nation Acad Sci USA. 2008; 105:11037-11038.

60. Halliwell B. Vitamin C: poison, prophylactic or panacea? Trends Biochem Sci. 1999; 24:255-259. [PubMed: 10390611]

61. Mc Cormick WJ. Cancer: a collagen disease, secondary to a nutritional deficiency. Arch Pediatr. 1959; 76:166-171. [PubMed: 13638066]

62. Cameron E, Pauling L. Ascorbic acid and the glycosaminoglycans. An orthomolecular approach to cancer and other diseases. Oncology. 1973; 27:181-192. [PubMed: 4267127]

63. Cameron E, Rotman D. Ascorbic acid, cell proliferation, and cancer. Lancet. 1972; 1:542. [PubMed: 4110043]

64. Cameron E, Campbell A. The orthomolecular treatment of cancer. II. Clinical trial of high-dose ascorbic acid supplements in advanced human cancer. Chemico-Biol Interac. 1974; 9:285-315.

65. Cameron E, Campbell A, Jack T. The orthomolecular treatment of cancer. III. Reticulum cell sarcoma: double complete regression induced by high-dose ascorbic acid therapy. Chemico-Biol Interac. 1975; 11:387-393.

66. Cameron E, Pauling L. Supplemental ascorbate in the supportive treatment of cancer: Prolongation of survival times in terminal human cancer. Proceed Nation Acad Sci USA. 1976; 73:3685-3689.

67. Cameron E, Pauling L. Supplemental ascorbate in the supportive treatment of cancer: reevaluation of prolongation of survival times in terminal human cancer. Proceed Nation Acad Sci USA. 1978; 75:4538-4542.

68. Creagan ET, Moertel CG, O’Fallon JR, Schutt AJ, O’Connell MJ, Rubin J, Frytak S. Failure of high-dose vitamin $\mathrm{C}$ (ascorbic acid) therapy to benefit patients with advanced cancer. A controlled trial. New Eng J Med. 1979; 301:687-690. [PubMed: 384241]

69. Moertel CG, Fleming TR, Creagan ET, Rubin J, O’Connell MJ, Ames MM. High-dose vitamin C versus placebo in the treatment of patients with advanced cancer who have had no prior chemotherapy. A randomized double-blind comparison. New Eng J Med. 1985; 312:137-141. [PubMed: 3880867] 
70. Levine M, Conry-Cantilena C, Wang Y, Welch RW, Washko PW, Dhariwal KR, Park JB, Lazarev A, Graumlich JF, King J, Cantilena LR. Vitamin C pharmacokinetics in healthy volunteers: evidence for a recommended dietary allowance. Proceed Nation Acad Sci USA. 1996; 93:37043709.

71. Padayatty SJ, Riordan HD, Hewitt SM, Katz A, Hoffer LJ, Levine M. Intravenously administered vitamin C as cancer therapy: three cases. CMAJ : Can Med Assoc J = J de l'Assoc Medicale Canadienne. 2006; 174:937-942.

72. Padayatty SJ, Levine M. New insights into the physiology and pharmacology of vitamin C. CMAJ : Can Med Assoc J = J de l'Assoc Medicale Canadienne. 2001; 164:353-355.

73. Chen Q, Espey MG, Sun AY, Pooput C, Kirk KL, Krishna MC, Khosh DB, Drisko J, Levine M. Pharmacologic doses of ascorbate act as a prooxidant and decrease growth of aggressive tumor xenografts in mice. Proceed Nation Acad Sci USA. 2008; 105:11105-11109.

74. Hoffer LJ, Levine M, Assouline S, Melnychuk D, Padayatty SJ, Rosadiuk K, Rousseau C, Robitaille L, Miller WH Jr. Phase I clinical trial of i.v. ascorbic acid in advanced malignancy. Annals Oncol : Offic J Eur Soc Med Oncol / ESMO. 2008; 19:1969-1974.

75. Verrax J, Calderon PB. Pharmacologic concentrations of ascorbate are achieved by parenteral administration and exhibit antitumoral effects. Free Radical Biol Med. 2009; 47:32-40. [PubMed: 19254759]

76. Chen Q, Espey MG, Krishna MC, Mitchell JB, Corpe CP, Buettner GR, Shacter E, Levine M. Pharmacologic ascorbic acid concentrations selectively kill cancer cells: action as a pro-drug to deliver hydrogen peroxide to tissues. Proceed Nation Acad Sci USA. 2005; 102:13604-13609.

77. Du J, Martin SM, Levine M, Wagner BA, Buettner GR, Wang SH, Taghiyev AF, Du C, Knudson $\mathrm{CM}$, Cullen JJ. Mechanisms of ascorbate-induced cytotoxicity in pancreatic cancer. Clin Canc Res : Offic J Am Assoc Canc Res. 2010; 16:509-520.

78. Heeg K, Reimann J, Kabelitz D, Hardt C, Wagner H. A rapid colorimetric assay for the determination of IL-2-producing helper T cell frequencies. J Immunol Methods. 1985; 77:237246. [PubMed: 3156935]

79. Coleman MC, Asbury CR, Daniels D, Du J, Aykin-Burns N, Smith BJ, Li L, Spitz DR, Cullen JJ. 2-deoxy-D-glucose causes cytotoxicity, oxidative stress, and radiosensitization in pancreatic cancer. Free Radical Biol Med. 2008; 44:322-331. [PubMed: 18215740]

80. Liu J, Hinkhouse MM, Sun W, Weydert CJ, Ritchie JM, Oberley LW, Cullen JJ. Redox regulation of pancreatic cancer cell growth: role of glutathione peroxidase in the suppression of the malignant phenotype. Human Gene Ther. 2004; 15:239-250. [PubMed: 15018733]

81. Oberley LW. Mechanism of the tumor suppressive effect of MnSOD overexpression. Biomed Pharmacother. 2005; 59:143-148. [PubMed: 15862707]

82. Schafer FQ, Buettner GR. Redox environment of the cell as viewed through the redox state of the glutathione disulfide/glutathione couple. Free Radical Biol Med. 2001; 30:1191-1212. [PubMed: 11368918]

83. Chen Q, Espey MG, Sun AY, Lee JH, Krishna MC, Shacter E, Choyke PL, Pooput C, Kirk KL, Buettner GR, Levine M. Ascorbate in pharmacologic concentrations selectively generates ascorbate radical and hydrogen peroxide in extracellular fluid in vivo. Proceed Nation Acad Sci USA. 2007; 104:8749-8754.

84. Brown JM, Grosso MA, Terada LS, Beehler CJ, Toth KM, Whitman GJ, Harken AH, Repine JE. Erythrocytes decrease myocardial hydrogen peroxide levels and reperfusion injury. Am J Physiol. 1989; 256:H584-588. [PubMed: 2916691]

85. Chance B, Sies H, Boveris A. Hydroperoxide metabolism in mammalian organs. Physiol Rev. 1979; 59:527-605. [PubMed: 37532]

86. Guemouri L, Artur Y, Herbeth B, Jeandel C, Cuny G, Siest G. Biological variability of superoxide dismutase, glutathione peroxidase, and catalase in blood. Clin Chem. 1991; 37:1932-1937. [PubMed: 1934468]

87. Motoyama S, Saito S, Inaba H, Kitamura M, Minamiya Y, Suzuki H, Saito R, Kamata S, Nakae H, Ogawa J. Red blood cells attenuate sinusoidal endothelial cell injury by scavenging xanthine oxidase-dependent hydrogen peroxide in hyperoxic perfused rat liver. Liver. 2000; 20:200-208.

[PubMed: 10902969] 
88. Low FM, Hampton MB, Winterbourn CC. Peroxiredoxin 2 and peroxide metabolism in the erythrocyte. Antioxi Redox Signal. 2008; 10:1621-1630.

89. May JM, Qu Z, Cobb CE. Recycling of the ascorbate free radical by human erythrocyte membranes. Free Radical Biol Med. 2001; 31:117-124. [PubMed: 11425497]

90. Baronzio G, Schwartz L, Kiselevsky M, Guais A, Sanders E, Milanesi G, Baronzio M, Freitas I. Tumor interstitial fluid as modulator of cancer inflammation, thrombosis, immunity and angiogenesis. Anticanc Res. 2012; 32:405-414.

91. Casciari JJ, Riordan NH, Schmidt TL, Meng XL, Jackson JA, Riordan HD. Cytotoxicity of ascorbate, lipoic acid, and other antioxidants in hollow fibre in vitro tumours. Brit J Canc. 2001; 84:1544-1550.

92. Halliwell B. Oxygen radicals, nitric oxide and human inflammatory joint disease. Annals Rheum Diseas. 1995; 54:505-510.

93. Klockars M, Weber T, Tanner P, Hellstrom PE, Pettersson T. Pleural fluid ferritin concentrations in human disease. J Clin Pathol. 1985; 38:818-824. [PubMed: 4019803]

94. Weinberger A, Simkin PA. Plasma proteins in synovial fluids of normal human joints. Semin Arthrit Rheumat. 1989; 19:66-76.

95. Du J, Nelson ES, Simons AL, Olney KE, Moser JC, Schrock HE, Wagner BA, Buettner GR, Smith BJ, Teoh ML, Tsao MS, Cullen JJ. Regulation of pancreatic cancer growth by superoxide. Mol Carcinogen. 2012

96. Antunes F, Cadenas E. Estimation of $\mathrm{H} 2 \mathrm{O} 2$ gradients across biomembranes. FEBS Lett. 2000; 475:121-126. [PubMed: 10858501]

97. Wang XY, Liu JK, Yokoi I, Kohno M, Mori A. Direct detection of circulating free-radicals in the rat using electron-spin-resonance spectrometry. Free Radical Bio Med. 1992; 12:121-126. [PubMed: 1313773]

98. Chepda T, Cadau M, Girin P, Frey J, Chamson A. Monitoring of ascorbate at a constant rate in cell culture: effect on cell growth. In vitro Cell Developm Biol Anim. 2001; 37:26-30.

99. Frikke-Schmidt H, Lykkesfeldt J. Keeping the intracellular vitamin C at a physiologically relevant level in endothelial cell culture. Analyt Biochem. 2010; 397:135-137. [PubMed: 19782654]

100. Fujiwara M, Nagao N, Monden K, Misumi M, Kageyama K, Yamamoto K, Miwa N. Enhanced protection against peroxidation-induced mortality of aortic endothelial cells by ascorbic acid-2O-phosphate abundantly accumulated in the cell as the dephosphorylated form. Free Radical Res. 1997; 27:97-104. [PubMed: 9269584]

101. Vislisel JM, Schafer FQ, Buettner GR. A simple and sensitive assay for ascorbate using a plate reader. Analyt Biochem. 2007; 365:31-39. [PubMed: 17433246]

102. Olney KE, Du J, van't Erve TJ, Witmer JR, Sibenaller ZA, Wagner BA, Buettner GR, Cullen JJ. Inhibitors of hydroperoxide metabolism enhance ascorbate-induced cytotoxicity. Free Radical Res. 2013; 47:154-163. [PubMed: 23205739]

103. Klingelhoeffer C, Kammerer U, Koospal M, Muhling B, Schneider M, Kapp M, Kübler A, Germer C-T, Otto C. Natural resistance to ascorbic acid induced oxidative stress is mainly mediated by catalase activity in human cancer cells and catalase-silencing sensitizes to oxidative stress. BMC Complement Alternat Med. 2012; 12:61.

104. Benade L, Howard T, Burk D. Synergistic killing of Ehrlich ascites carcinoma cells by ascorbate and 3-amino-1,2,4,-triazole. Oncology. 1969; 23:33-43. [PubMed: 5774953]

105. Richardson DR, Ponka P. The molecular mechanisms of the metabolism and transport of iron in normal and neoplastic cells. Biochim Biophys Acta. 1997; 1331:1-40. [PubMed: 9325434]

106. Wang W, Knovich MA, Coffman LG, Torti FM, Torti SV. Serum ferritin: Past, present and future. Biochim Biophys Acta. 2010; 1800:760-769. [PubMed: 20304033]

107. Buettner GR, Chamulitrat W. The catalytic activity of iron in synovial fluid as monitored by the ascorbate free radical. Free Radical Biol Med. 1990; 8:55-56. [PubMed: 2157634]

108. Dabbagh AJ, Trenam CW, Morris CJ, Blake DR. Iron in joint inflammation. Annals Rheumat Dis. 1993; 52:67-73.

109. Galley HF, Davies MJ, Webster NR. Ascorbyl radical formation in patients with sepsis: effect of ascorbate loading. Free Radical Biol Med. 1996; 20:139-143. [PubMed: 8903690] 
110. Coudray C, Pucheu S, Boucher F, Arnaud J, de Leiris J, Favier A. Effect of ischemia/reperfusion sequence on cytosolic iron status and its release in the coronary effluent in isolated rat hearts. Biolog Trace Elem Res. 1994; 41:69-75.

111. Spencer KT, Lindower PD, Buettner GR, Kerber RE. Transition metal chelators reduce directly measured myocardial free radical production during reperfusion. J Cardiovas Pharmacol. 1998; 32:343-348.

112. Basso D, Fabris C, Del Favero G, Meggiato T, Panozzo MP, Vianello D, Plebani M, Naccarato R. Hepatic changes and serum ferritin in pancreatic cancer and other gastrointestinal diseases: the role of cholestasis. Annals Clinic Biochem. 1991; 28(Pt 1):34-38.

113. Guner G, Kirkali G, Yenisey C, Tore IR. Cytosol and serum ferritin in breast carcinoma. Canc Lett. 1992; 67:103-112.

114. Miyata Y, Koga S, Nishikido M, Hayashi T, Kanetake H. Relationship between serum ferritin levels and tumour status in patients with renal cell carcinoma. BJU Internat. 2001; 88:974-977.

115. Rossiello R, Carriero MV, Giordano GG. Distribution of ferritin, transferrin and lactoferrin in breast carcinoma tissue. J Clin Pathol. 1984; 37:51-55. [PubMed: 6323544]

116. Jacobs A. Serum ferritin and malignant tumours. Medic Oncol Tumor Pharmacother. 1984; 1:149-156.

117. Tian J, Peehl DM, Knox SJ. Metalloporphyrin synergizes with ascorbic acid to inhibit cancer cell growth through fenton chemistry. Canc Biother Radiopharmaceut. 2010; 25:439-448.

118. Zhong W, Yan T, Webber MM, Oberley TD. Alteration of cellular phenotype and responses to oxidative stress by manganese superoxide dismutase and a superoxide dismutase mimic in RWPE-2 human prostate adenocarcinoma cells. A Antioxid Redox Signal. 2004; 6:513-522. [PubMed: 15130278]

119. Batinic-Haberle I, Reboucas JS, Spasojevic I. Superoxide dismutase mimics: chemistry, pharmacology, and therapeutic potential. Antioxid Redox Signal. 2010; 13:877-918. [PubMed: 20095865]

120. Carmine TC, Evans P, Bruchelt G, Evans R, Handgretinger R, Niethammer D, Halliwell B. Presence of iron catalytic for free radical reactions in patients undergoing chemotherapy: implications for therapeutic management. Canc Lett. 1995; 94:219-226.

121. Persson HL. Radiation-induced lysosomal iron reactivity: implications for radioprotective therapy. IUBMB Life. 2006; 58:395-401. [PubMed: 16801214]

122. Reif DW. Ferritin as a source of iron for oxidative damage. Free Radical Biol Med. 1992; 12:417427. [PubMed: 1317328]

123. Espey MG, Chen P, Chalmers B, Drisko J, Sun AY, Levine M, Chen Q. Pharmacologic ascorbate synergizes with gemcitabine in preclinical models of pancreatic cancer. Free Radical Biol Med. 2011; 50:1610-1619. [PubMed: 21402145]

124. Campbell GD Jr, Steinberg MH, Bower JD. Letter: Ascorbic acid-induced hemolysis in G-6-PD deficiency. Annals Intern Med. 1975; 82:810.

125. Mehta JB, Singhal SB, Mehta BC. Ascorbic-acid-induced haemolysis in G-6-PD deficiency. Lancet. 1990; 336:944. [PubMed: 1976956]

126. Rees DC, Kelsey H, Richards JD. Acute haemolysis induced by high dose ascorbic acid in glucose-6-phosphate dehydrogenase deficiency. BMJ. 1993; 306:841-842. [PubMed: 8490379]

127. Wong K, Thomson C, Bailey RR, McDiarmid S, Gardner J. Acute oxalate nephropathy after a massive intravenous dose of vitamin C. Aus New Zealand J Med. 1994; 24:410-411.

128. Fleming RE, Ponka P. Iron overload in human disease. New Eng J Med. 2012; 366:348-359. [PubMed: 22276824]

129. Campbell A, Jack T. Acute reactions to mega ascorbic acid therapy in malignant disease. Scott Medical J. 1979; 24:151-153.

130. Monti DA, Mitchell E, Bazzan AJ, Littman S, Zabrecky G, Yeo CJ, Pillai MV, Newberg AB, Deshmukh S, Levine M. Phase I evaluation of intravenous ascorbic acid in combination with gemcitabine and erlotinib in patients with metastatic pancreatic cancer. PloS One. 2012; 7:e29794. [PubMed: 22272248] 
131. Riordan HD, Casciari JJ, Gonzalez MJ, Riordan NH, Miranda-Massari JR, Taylor P, Jackson JA. A pilot clinical study of continuous intravenous ascorbate in terminal cancer patients. Puerto Rico Health Sci J. 2005; 24:269-276.

132. Stephenson CM, Levin RD, Spector T, Lis CG. Phase I clinical trial to evaluate the safety, tolerability, and pharmacokinetics of high-dose intravenous ascorbic acid in patients with advanced cancer. Canc Chemother Pharmacol. 2013; 72:139-146.

133. Tahahashi H, Mizuno H, Yanagisawa A. High-dose intravenous vitamin C improves quality of life in cancer patients. Personal Med Universe. 2012; 1:49-53.

134. Riordan HD, Riordan NH, Jackson JA, Casciari JJ, Hunninghake R, Gonzalez MJ, Mora EM, Miranda-Massari JR, Rosario N, Rivera A. Intravenous vitamin C as a chemotherapy agent: a report on clinical cases. Puerto Rico Health Sci J. 2004; 23:115-118.

135. Kato J, Nagahara A, Iijima K, Yoshimura M, Osada T, Yoshizawa T, Watanabe S. Evaluation of EORTC QLQ-C30 questionnaire in patients undergoing in-hospital chemotherapy for gastrointestinal cancer in Japan. J Gastroenterol Hepatol. 2008; 23(Suppl 2):S268-272. [PubMed: 19120910]

136. Kobayashi K, Takeda F, Teramukai S, Gotoh I, Sakai H, Yoneda S, Noguchi Y, Ogasawara H, Yoshida K. A cross-validation of the European Organization for Research and Treatment of Cancer QLQ-C30 (EORTC QLQ-C30) for Japanese with lung cancer. Eur J Canc. 1998; 34:810 815.

137. Farrar JT, Young JP Jr, LaMoreaux L, Werth JL, Poole RM. Clinical importance of changes in chronic pain intensity measured on an 11-point numerical pain rating scale. Pain. 2001; 94:149158. [PubMed: 11690728]

138. Riordan HD, Hunninghake RB, Riordan NH, Jackson JJ, Meng X, Taylor P, Casciari JJ, González MJ, Miranda-Massari JR, Mora EM, Rosario N, Rivera A. Intravenous ascorbic acid: protocol for its application and use. Puerto Rico Health Sci J. 2003; 22:287-290.

139. Eisenhauer EA, Therasse P, Bogaerts J, Schwartz LH, Sargent D, Ford R, Dancey J, Arbuck S, Gwyther S, Mooney M, Rubinstein L, Shankar L, Dodd L, Kaplan R, Lacombe D, Verweij J. New response evaluation criteria in solid tumours: revised RECIST guideline (version 1.1). Eur J Canc. 2009; 45:228-247.

140. Welsh JL, Wagner BA, van't Erve TJ, Zehr PS, Berg DJ, Halfdanarson TR, Yee NS, Bodeker KL, Du J, Roberts LJ 2nd, Drisko J, Levine M, Buettner GR, Cullen JJ. Pharmacological ascorbate with gemcitabine for the control of metastatic and node-positive pancreatic cancer (PACMAN): results from a phase I clinical trial. Canc Chemother Pharmacol. 2013; 71:765-775.

141. Buettner GR, Jurkiewicz BA. Ascorbate free radical as a marker of oxidative stress: an EPR study. Free Radical Biol Med. 1993; 14:49-55. [PubMed: 8384150]

142. Morrow JD, Hill KE, Burk RF, Nammour TM, Badr KF, Roberts LJ 2nd. A series of prostaglandin F2-like compounds are produced in vivo in humans by a non-cyclooxygenase, free radical-catalyzed mechanism. Proceed Nat Acad Sci USA. 1990; 87:9383-9387.

143. Herst PM, Broadley KW, Harper JL, McConnell MJ. Pharmacological concentrations of ascorbate radiosensitize glioblastoma multiforme primary cells by increasing oxidative DNA damage and inhibiting G2/M arrest. Free Radical Biol Med. 2012; 52:1486-1493. [PubMed: 22342518]

144. Shinozaki K, Hosokawa Y, Hazawa M, Kashiwakura I, Okumura K, Kaku T, Nakayama E. Ascorbic acid enhances radiation-induced apoptosis in an HL60 human leukemia cell line. J Radiat Res. 2011; 52:229-237. [PubMed: 21343676] 


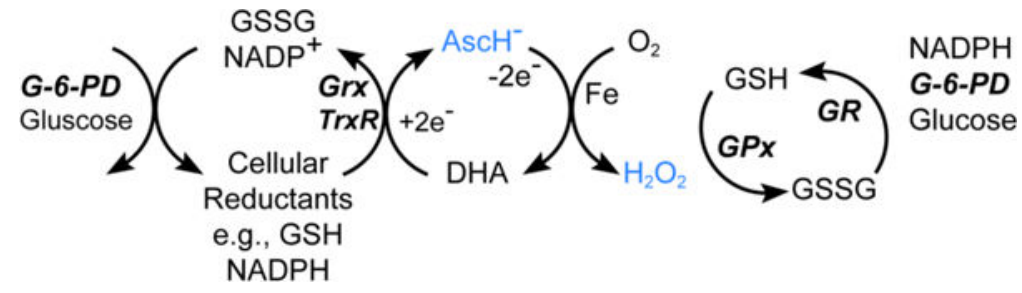

Fig. 1.

Ascorbate oxidation results in a 2-electron reduction of dioxygen forming $\mathrm{H}_{2} \mathrm{O}_{2}$. G-6-PD = glucose-6-phosphate dehydrogenase; GPx = glutathione peroxidase; GR = glutathione disulfide reductase; Grx = glutaredoxin; GSH = glutathione; GSSG = glutathione disulfide; $\operatorname{Trx}=$ thioredoxin. 


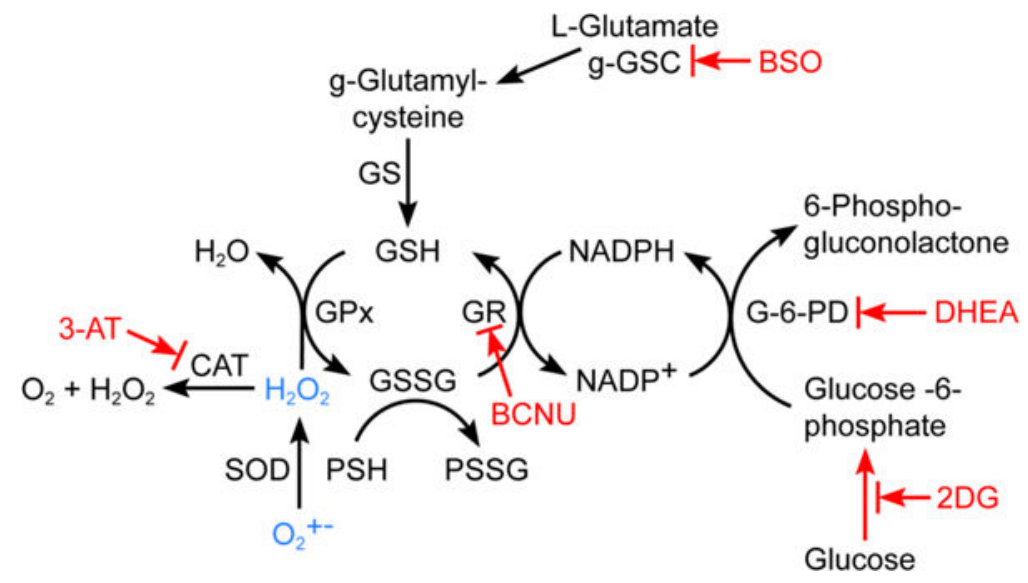

Fig. 2.

Antioxidant enzyme schematic. GSH = glutathione; GSSG = glutathione disulfide; GR = glutathione disulfide reductase; G-6-PD = glucose-6-phosphate dehydrogenase; ${ }^{\gamma} \mathrm{GCS}=$ gamma-glutamylcysteine synthetase; GPx = glutathione peroxidase; GS = glutathione synthetase. Inhibitors of the pathway are: 3 -AT=3-amino-1,2,4-triazole; $\mathrm{BCNU}=1,3$ bis (2chloroethyl)-1-nitrosurea; $\mathrm{BSO}=$ buthionine sulfoximine; $2 \mathrm{DG}=2$-deoxy-D-glucose. 


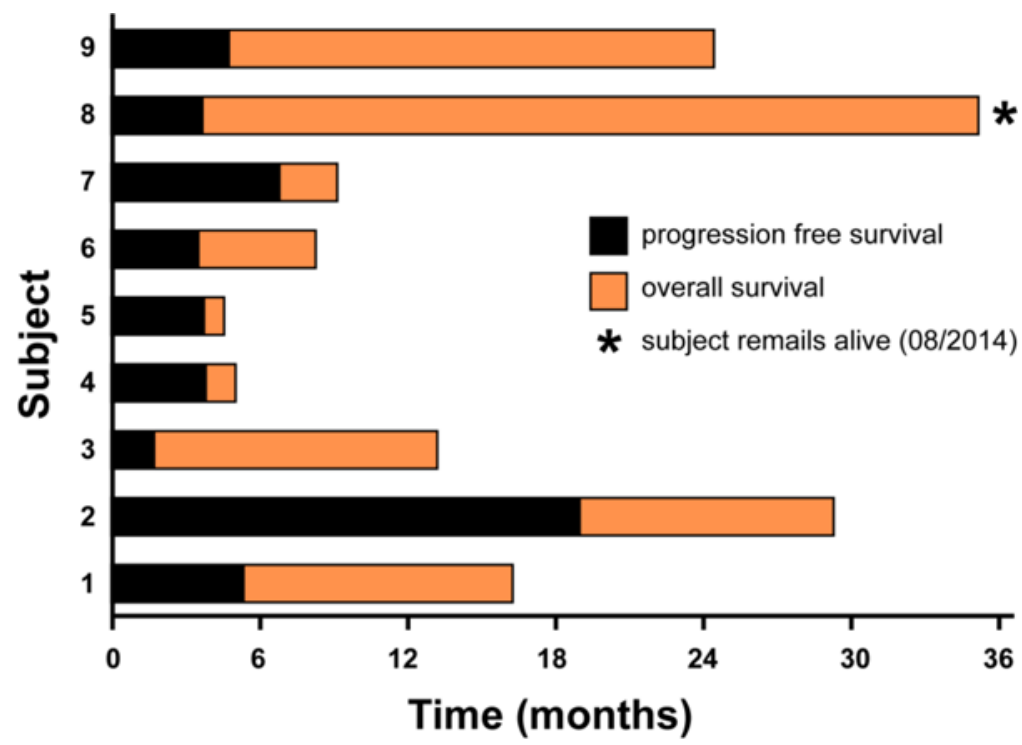

Fig. 3.

Progression free and overall survival. This phase I trial was designed to determine the effect of escalating doses of ascorbate when combined with gemcitabine in stage IV pancreatic cancer patients. The trial utilized a modified Burris regimen, administering gemcitabine for 3 weeks for each cycle of therapy along with ascorbate given twice weekly for every week. Historic median survival for gemcitabine-treated patients alone is 5.65 months. The mean survival in our study currently stands at 15 months. 